\title{
Effect of Organic Acid Salts as an Alternative to Antibiotic Growth Promoters on the Production Performance of Commercial Broiler Chicken
}

\author{
S. Naveenkumar ${ }^{1 *}$, N. Karthikeyan ${ }^{2}$, R. Narendra Babu ${ }^{3}$, P. Veeramani ${ }^{4}$ and \\ S. Sivaramakrishnan ${ }^{1}$
}

${ }^{1}$ Department of Poultry Science, MVC, Chennai-07, Tamil Nadu, India

${ }^{2}$ Poultry Research Station, Chennai-51, Tamil Nadu, India

${ }^{3}$ Department of Livestock products Technology, MVC, Chennai-07, Tamil Nadu, India

${ }^{4}$ Farmers Training Centre, TANUVAS, Kancheepuram - 631 561, Tamil Nadu, India

*Corresponding author

\section{A B S T R A C T}

\section{Keywords \\ Organic acid, Calcium propionate, Sodium butyrate, Production performance and Alternative to antibiotic growth promoters.}

Article Info

Accepted:

10 July 2017

Available Online:

10 September 2017
An experiment was conducted with 240 day old commercial broiler chicks to evaluate the effectiveness of replacing antibiotic growth promoters with organic acid salts on the production performance. Treatment diets were supplemented with lincomycin $\mathrm{HCl}(4.4$ ppm), bacitracin methylene disalicylate (BMD; $50 \mathrm{ppm})$, each two levels (ppm) of calcium propionate $(1000,2000)$ and coated sodium butyrate $(500,1000)$ either alone or in combination $(1000+500)$ with control. The results showed that there was no significant difference in body weight, body weight gain, cumulative feed intake, FCR and livability among the treatment groups. However, the calcium propionate (2000) group had the highest body weight gain with $6.48 \%$ more than lower levels (1000). Improved EEF and COP were observed in organic acid treated groups. Calcium propionate and coated sodium butyrate could be safely supplemented as an alternative to antibiotic growth promoters (AGPs) in the commercial broiler diet without affecting the production performance.

\section{Introduction}

The use of in fed antibiotics for growth promotion had been arisen with the intensification of livestock farming. Administration of sub-therapeutic level of antibiotics and antimicrobial agents is widely practiced so as to control the infectious agents and to improve the productivity of food animals. Currently, there is a controversy surrounding the use of antibiotic growth promoters (AGPs) for animals destined for meat production, as overuse of any antibiotic over a period of time may lead to resistance of these bacterial populations to the antibiotic used. Which in-turn affect human health either directly through residues of an antibiotic in meat or indirectly through the selection of antibiotic resistance determinants that may spread to human pathogen.

In 2006, the European Union imposed a complete ban on the use of antibiotics in animal feed as growth promoters. World Health Organization (WHO) along with World Organization for Animal Health (OIE) 
encourages the health, agriculture, veterinary sector for reducing the injudicious use of antibiotics as growth promoters and further to decrease the spread of resistant bacteria (Cogliani et al., 2011).

Therefore, other non-therapeutic alternatives such as probiotics, prebiotics, symbiotics, antimicrobial peptides, enzymes, essential oils, eucalyptus oil, organic acids, clay minerals, egg yolk antibodies, rare earth elements, recombinant enzymes and immunostimulants have been introduced as an alternative to the antibiotic growth promoters.

Among the alternatives, organic acids could be considered as the best possible choice for securing the supply of safe food. Acidification increases gastric proteolysis, protein and amino acid digestibility and utilization of minerals and thus improving the performance of the birds (Haque et al., 2009). Organic acids (propionic acid and butyric acid) effectively replace the antibiotics and improve the production performance like body weight gain and FCR (Vijayalakshmi et al., 2015; Adil et al., 2011; Deepa et al., 2016).

The efficiency of the calcium propionate and coated sodium butyrate was not much studied as an alternative to commonly incorporated antibiotic growth promoters such as lincomycin hydrochloride and bacitracin methylene disalicylate (BMD) in the commercial broiler chicken feed in India. Hence, the present study was undertaken to evaluate the response of calcium propionate and coated sodium butyrate at different levels either alone or in combination as an alternative to antibiotic growth promoters such as lincomycin hydrochloride and bacitracin methylene disalicylate (BMD) to assess the production performance and cost of production of the commercial broiler chicken fed with calcium propionate and the salt of butyric acid.

\section{Materials and Methods}

A six week biological experiment was conducted in commercial broiler chicken at Poultry Research Station, TANUVAS, MMC, Chennai. The birds were reared in brooder cages for first two weeks; then they were shifted to grower cages till the end of the experiment. The birds were provided with 450 and $929 \mathrm{~cm}^{2}$ floor spaces per bird during brooding and growing periods, respectively. The feeding space provided was 3.0 and 7.0 $\mathrm{cm}$ per bird during brooding and growing period respectively. The watering space provided in the form of one nipple for 3 birds during brooding and growing period. The chicks were vaccinated against Ranikhet disease [RDVF (day seven), RDV-Lasota (day 28)] and Infectious Bursal Disease (Intermediate Georgia strain; day 14).

The experiment was split into pre-starter (0$14 \mathrm{~d})$, starter (15-28 d) and finisher (29-42 d) periods. For this study, 240 number of unsexed day old chicks (COBB 400) were randomly distributed into eight treatment groups with three replicates each (10 chicks per replicate). They were fed with cornsoybean meal based basal diet (unsupplemented control) or the basal diet with a antibiotic growth promoters (lincomycin; $4.4 \mathrm{ppm}$ and BMD; $50 \mathrm{ppm}$ ) or organic acids (OAs) such as calcium propionate (1000 or $2000 \mathrm{ppm})$ and coated sodium butyrate (500 or $1000 \mathrm{ppm})$ either alone or in combination (CP $1000+\mathrm{SB} 500)$ for a period of 42 days.

The body weight of the birds was recorded on day one and every week up to 6 weeks during morning. All treatment groups were provided with ad libitum feeding. Feed to gain ratio for each replicate was arrived by dividing average feed consumption by average body weight. Mortality (if any) of birds was recorded during the experimental period of 6 
weeks and the livability was calculated. European economic factor was calculated as [Livability x Average body weight) / (Mean Age (days) x FCR)] x 100

Cost of Production includes all total input cost/ total kg of chicken sold. Production cost (per kg live weight) was calculated from the chick cost (35 Rs./chick), feed cost, miscellaneous cost (labour cost, medicine and vaccination cost, electricity, etc.; Rs. 5 per kg live weight).

\section{Results and Discussion}

\section{Body weight and weight gain}

Among treatment groups, there was a nonsignificant $(\mathrm{P}>0.05)$ increase in body weight (Table 1) and weight gain (Table 2) was noticed due to the dietary incorporation of organic acids like calcium propionate $(\mathrm{CP})$ and coated sodium butyrate (SB) during the entire experimental period of sixth weeks. However, the groups supplemented with organic acid had numerically higher body weight gain than AGPs supplemented and unsupplemented control groups.

Among various treatment groups calcium propionate supplemented at the dose rate of 2000 ppm (T4) showed an increasing trend in the body weight gain from the first to sixth week of age with a difference in magnitude in body weight gain was higher at 6.65 per cent between the groups supplemented with two levels of calcium propionate. The cumulative body weight gain among the groups ranged from the lowest $1865 \mathrm{~g}$ in T3 (CP 1000) to the highest $1989 \mathrm{~g} /$ bird in T4 (CP 2000). Dose dependent response was noticed in the groups supplemented with any of the OAs either alone or in combination. The body weight gain obtained in this study with respect to higher level organic acid inclusion agreed with the result of Oruwari et al., (1993) who observed calcium propionate increased the body weight at the dose rate of $1 \mathrm{~g} / \mathrm{kg}$ and also agreed with Khosravi et al., (2008) who had incorporated the calcium propionate at the dose rate of $2 \mathrm{~g} / \mathrm{kg}$. Likewise, in coated sodium butyrate supplemented treatment, results were in agreement with $\mathrm{Hu}$ and $\mathrm{Guo}$ (2007), Czerwinski et al., 2012, Brozoska et al., (2013) reiterated that sodium butyrate added to the diets broiler enhanced the body weight gain. The organic acid incorporated in the diet might have a positive influence on the digestibility of in-fed nutrients, improves the gut health and that could be the reason for higher body weight gain in the groups supplemented with OAs and the same can be confirmed with the dose dependant improvement noticed in the body weight gain in those groups.

\section{Feed consumption}

Supplementation of AGPs and OAs did not significantly influence the feed consumption (Table 3) among treatment groups. However the unsupplemented control group had lower feed intake than other groups during the overall period. The groups supplemented with higher doses of organic acid had a higher feed intake. The groups supplemented with AGPs forms a second line in the cumulative feed consumption. The cumulative feed consumption (FC) ranged from the lowest $3305 \mathrm{~g}$ (BMD) to the highest $3557 \mathrm{~g}$ (CP; 2000 ppm; T4) which did not differ due to various dietary treatments though an apparent increase in FC was noticed on the groups supplemented with calcium propionate at 2000 ppm (T4).

The reduction in feed intake in unsupplemented control group might be due to the presence of mild infection in the gasterointestinal tract (GIT) due to pathogenic load which might lead to inflammation that releases proinflammatory cytokines (TNF- $\alpha$ ) 
into cerebral ventricles potently blocking appetite despite free access to feed (Tracey et al., 1990) and enhancing muscle catabolism (Klasing- cited by khadem et al., 2014). The increased feed intake in AGPs supplemented groups may also explained as the antimicrobial drugs are known to improve the digestibility of nutrients by improving the structure of intestinal flora. This increased digestibility might have enhanced the rate of passage of feed that resulted in increased feed intake (Midtvedt, 1986 and Norin, 1997). Further, sodium butyrate has the ability to increase the gastric emptying and intestinal motility thereby increasing feed intake (Malbert et al., 1994). In addition to that butyrate and propionate induced phasic and tonic contraction in colonic circular muscle (Mitsui et al., 2005; Tazoe et al., 2008) also butyrate has been reported to induce enhancement of colonic motility via the release of 5-HT (Fukumoto et al., 2003).

\section{Feed efficiency}

Supplementation of AGPs and OAs did not significantly $(\mathrm{P}>0.05)$ influence the feed efficiency (Table 4) among treatment groups throughout the period. The mean feed efficiency ranged from better 1.751 (C) to poor 1.817 (T6; SB 1000) among treatments. This result is in agreement with the findings of Shahir et al., (2013); Better feed efficiency was noted in T5 (SB 500) when compared among the groups supplemented with AGPs and OAs. Unsupplemented control groups had a better feed efficiency (1.751) than all other treatment groups, might be due to lower feed intake that may lead to better utilization nutrients at cellular level. In addition, as the entire experimental trail was conducted in the brooder cum grower cages, there may be little chances of getting the pathogenic microbes entering in to the GIT from its own litter which is the ultimate source of infection in the birds maintained in the deep litter system of management. Among the groups supplemented with organic acid, higher doses of supplementation results in poor feed efficiency than their respective groups supplemented with lower doses. Similar trend was noticed in the groups supplemented with calcium propionate at the dose rate of 2000 ppm (T4) which had a poor feed efficiency than other treatment groups with the value of 1.812. An improvement in the live performance of the birds particularly in higher body weight and body weight gain which was noticed in the groups supplemented with higher level of OAs might be attributed to the higher level of feed consumption in those groups. This higher quantum of feed consumption might be the reason for poor feed efficiency noticed in those groups.

\section{Livability}

During the biological experiment of six wks duration, there was a hundred per cent livability was observed among all the treatment groups up to the age of five weeks. During the sixth week of experimental period, the mortality happened in six groups out of eight treatment groups due to heat stroke.

The data on the mean livability of commercial broiler chicken as influenced by supplementation of AGPs and OAs did not significantly affect the livability among the treatment groups. The control groups had lowest livability (76.66 \%) whereas lincomycin supplemented groups (T1) had $83.33 \%$ and BMD supplemented groups (T2) had $93.33 \%$ livability. Average livability in AGPs supplemented was $88.33 \%$ whereas OAs supplemented groups was $92.66 \%$. The groups supplemented with OAs at lower doses (T3 and T5) had a fructiferous livability up to sixth week of age with $100 \%$. This might be due to the enhanced immune status and suppression of pathogenic bacteria by organic acids. 
Table.1 Effect of in fed calcium propionate (CP) and coated sodium butyrate (SB) as growth promoters on the live body weight (g) in commercial broiler chicken (Mean $\pm \mathrm{SE}$ )

\begin{tabular}{|c|c|c|c|c|c|c|c|}
\hline \multirow{2}{*}{$\begin{array}{c}\text { Treatment } \\
\text { (ppm) }\end{array}$} & \multicolumn{7}{|c|}{ Age (wks) } \\
\hline & Day Old & 1 & 2 & 3 & 4 & 5 & 6 \\
\hline $\begin{array}{c}\mathrm{C} ; \\
\text { Control }\end{array}$ & $48.12 \pm 0.71$ & $\begin{array}{c}154.20 \pm \\
2.45\end{array}$ & $\begin{array}{c}385.46 \pm \\
4.96\end{array}$ & $\begin{array}{c}771.40 \pm \\
8.38\end{array}$ & $\begin{array}{c}1229.53 \pm \\
18.00\end{array}$ & $\begin{array}{c}1689.23 \pm \\
29.94\end{array}$ & $\begin{array}{c}1964.50 \pm \\
42.83\end{array}$ \\
\hline $\begin{array}{c}\mathrm{T} 1 ; \\
\text { Lincomycin } \mathrm{HCl}- \\
4.4\end{array}$ & $47.78 \pm 0.75$ & $\begin{array}{c}150.60 \pm \\
3.41\end{array}$ & $\begin{array}{c}378.66 \pm \\
10.70\end{array}$ & $\begin{array}{c}748.46 \pm \\
19.49\end{array}$ & $\begin{array}{c}1176.26 \pm \\
27.63\end{array}$ & $\begin{array}{c}1656.53 \pm \\
30.74\end{array}$ & $\begin{array}{c}1965.66 \pm \\
40.09\end{array}$ \\
\hline $\begin{array}{c}\text { T2; } \\
\text { BMD - } 50\end{array}$ & $46.76 \pm 0.74$ & $\begin{array}{c}152.70 \pm \\
2.13\end{array}$ & $\begin{array}{c}393.23 \pm \\
5.88\end{array}$ & $\begin{array}{c}769.16 \pm \\
11.86\end{array}$ & $\begin{array}{c}1214.66 \pm \\
21.95\end{array}$ & $\begin{array}{c}1681.03 \pm \\
33.40\end{array}$ & $\begin{array}{c}1937.32 \pm \\
37.97\end{array}$ \\
\hline $\begin{array}{c}\mathrm{T} 3 ; \\
\mathrm{CP}-1000\end{array}$ & $47.65 \pm 0.72$ & $\begin{array}{c}149.06 \pm \\
3.09\end{array}$ & $\begin{array}{c}373.76 \pm \\
7.52\end{array}$ & $\begin{array}{c}732.33 \pm \\
13.65\end{array}$ & $\begin{array}{c}1161.60 \pm \\
23.81\end{array}$ & $\begin{array}{c}1639.40 \pm \\
29.44\end{array}$ & $\begin{array}{c}1913.20 \pm \\
30.30\end{array}$ \\
\hline $\begin{array}{c}\mathrm{T} 4 ; \\
\mathrm{CP}-2000\end{array}$ & $47.40 \pm 0.77$ & $\begin{array}{c}157.20 \pm \\
3.04\end{array}$ & $\begin{array}{c}398.20 \pm \\
5.58\end{array}$ & $\begin{array}{c}772.83 \pm \\
13.28\end{array}$ & $\begin{array}{c}1238.96 \pm \\
21.74\end{array}$ & $\begin{array}{c}1747.06 \pm \\
34.89\end{array}$ & $\begin{array}{c}2037.23 \pm \\
42.83\end{array}$ \\
\hline $\begin{array}{c}\text { T5; } \\
\text { SB - 500 }\end{array}$ & $47.41 \pm 0.82$ & $\begin{array}{c}157.76 \pm \\
2.83\end{array}$ & $\begin{array}{c}385.46 \pm \\
6.63\end{array}$ & $\begin{array}{c}761.46 \pm \\
10.91\end{array}$ & $\begin{array}{c}1179.73 \pm \\
18.76\end{array}$ & $\begin{array}{c}1667.23 \pm \\
30.74\end{array}$ & $\begin{array}{c}1928.70 \pm \\
35.44\end{array}$ \\
\hline $\begin{array}{c}\text { T6; } \\
\text { SB - } 1000\end{array}$ & $47.89 \pm 0.64$ & $\begin{array}{c}153.10 \pm \\
3.03\end{array}$ & $\begin{array}{c}397.23 \pm \\
7.07\end{array}$ & $\begin{array}{c}771.73 \pm \\
11.77\end{array}$ & $\begin{array}{c}1220.30 \pm \\
21.27\end{array}$ & $\begin{array}{c}1671.20 \pm \\
36.18\end{array}$ & $\begin{array}{c}1964.77 \pm \\
41.64\end{array}$ \\
\hline $\begin{array}{c}\mathrm{T} 7 \\
\mathrm{CP}-1000+\mathrm{SB}- \\
500\end{array}$ & $47.63 \pm 0.77$ & $\begin{array}{c}154.53 \pm \\
2.28\end{array}$ & $\begin{array}{c}387.26 \pm \\
7.38\end{array}$ & $\begin{array}{c}768.66 \pm \\
14.65\end{array}$ & $\begin{array}{c}1227.46 \pm \\
22.62\end{array}$ & $\begin{array}{c}1685.86 \pm \\
30.69\end{array}$ & $\begin{array}{c}1943.03 \pm \\
31.77\end{array}$ \\
\hline F value & 0.300 & 1.119 & 1.440 & 1.170 & 1.725 & 0.979 & 1.010 \\
\hline Significance & NS & NS & NS & NS & NS & NS & NS \\
\hline
\end{tabular}

Means bearing different superscripts within the same column differ significantly; **Highly significant $(\mathrm{P}<0.01)$; Significant $(\mathrm{P}<0.05)$; NS - Non significant (P> 0.05); Dose of coated sodium butyrate was calculated based on the actual quantum of butyric acid present in it. 
Table.2 Effect of in fed calcium propionate (CP) and coated sodium butyrate (SB) as growth promoters on the cumulative body weight gain $(\mathrm{g})$ in commercial broiler chicken $($ Mean $\pm \mathrm{SE}$ )

\begin{tabular}{|c|c|c|c|c|c|c|}
\hline \multirow{2}{*}{$\begin{array}{c}\text { Treatment } \\
\text { (ppm) }\end{array}$} & \multicolumn{6}{|c|}{ Experimental period (wks) } \\
\hline & 1 & 2 & 3 & 4 & 5 & 6 \\
\hline $\begin{array}{c}\text { C; } \\
\text { Control }\end{array}$ & $106.07 \pm 2.30$ & $337.34 \pm 4.90$ & $723.27 \pm 8.46$ & $1181.40 \pm 18.07$ & $1641.10 \pm 30.13$ & $1915.83 \pm 43.15$ \\
\hline $\begin{array}{c}\mathrm{T} 1 ; \\
\underset{4.4}{\text { Lincomycin }} \mathrm{HCl}-\end{array}$ & $102.82 \pm 3.39$ & $330.88 \pm 10.57$ & $700.68 \pm 19.54$ & $1128.48 \pm 27.55$ & $1608.75 \pm 30.71$ & $1917.73 \pm 39.97$ \\
\hline $\begin{array}{c}\text { T2; } \\
\text { BMD }-50\end{array}$ & $105.94 \pm 2.13$ & $346.47 \pm 5.78$ & $722.40 \pm 11.77$ & $1167.90 \pm 21.94$ & $1634.27 \pm 33.33$ & $1890.66 \pm 37.87$ \\
\hline $\begin{array}{c}\text { T3; } \\
\text { CP - } 1000\end{array}$ & $101.41 \pm 3.02$ & $326.11 \pm 7.37$ & $684.68 \pm 13.49$ & $1113.95 \pm 23.63$ & $1591.75 \pm 29.37$ & $1865.55 \pm 30.20$ \\
\hline $\begin{array}{c}\mathrm{T} 4 \\
\mathrm{CP}-2000\end{array}$ & $109.80 \pm 2.84$ & $350.80 \pm 5.43$ & $725.43 \pm 13.01$ & $1191.56 \pm 21.46$ & $1699.66 \pm 34.56$ & $1989.33 \pm 42.43$ \\
\hline $\begin{array}{c}\mathrm{T} 5 \\
\mathrm{SB}-500\end{array}$ & $110.35 \pm 2.45$ & $338.05 \pm 6.23$ & $714.05 \pm 10.54$ & $1132.32 \pm 18.45$ & $1619.82 \pm 30.47$ & $1881.28 \pm 35.12$ \\
\hline $\begin{array}{c}\text { T6; } \\
\text { SB - } 1000\end{array}$ & $105.20 \pm 2.85$ & $349.34 \pm 6.83$ & $723.84 \pm 11.64$ & $1172.40 \pm 21.19$ & $1623.30 \pm 36.26$ & $1917.02 \pm 41.63$ \\
\hline $\begin{array}{c}\mathrm{T} 7 \\
\mathrm{CP}-1000+\mathrm{SB}- \\
500\end{array}$ & $106.90 \pm 2.16$ & $339.63 \pm 7.23$ & $721.03 \pm 14.47$ & $1179.83 \pm 22.49$ & $1638.23 \pm 30.57$ & $1895.55 \pm 31.66$ \\
\hline F value & 1.310 & 1.555 & 1.199 & 1.744 & 0.988 & 1.005 \\
\hline Significance & NS & NS & NS & NS & NS & NS \\
\hline
\end{tabular}

Means bearing different superscripts within the same column differ significantly; **Highly significant $(\mathrm{P}<0.01)$; Significant $(\mathrm{P}<0.05)$; NS $-\mathrm{Non}$ significant $(\mathrm{P}>0.05)$. 
Table.3 Effect of in fed calcium propionate (CP) and coated sodium butyrate (SB) as growth promoters on cumulative feed consumption $(\mathrm{g})$ in commercial broiler chicken (Mean $\pm \mathrm{SE}$ )

\begin{tabular}{|c|c|c|c|c|c|c|}
\hline \multirow{2}{*}{$\begin{array}{c}\text { Treatment } \\
(\mathbf{p p m})\end{array}$} & \multicolumn{6}{|c|}{ Experimental period (wks) } \\
\hline & 1 & 2 & 3 & 4 & 5 & 6 \\
\hline $\begin{array}{c}\mathrm{C} ; \\
\text { Control }\end{array}$ & $135.30 \pm 2.55$ & $470.30 \pm 23.05$ & $\begin{array}{c}1040.23 \pm \\
29.69\end{array}$ & $\begin{array}{l}1796.43 \pm \\
50.08\end{array}$ & $\begin{array}{c}2665.93 \pm \\
67.47\end{array}$ & $\begin{array}{c}3226.93 \pm \\
141.14\end{array}$ \\
\hline $\begin{array}{c}\mathrm{T} 1 ; \\
\text { Lincomycin } \mathrm{HCl}-4.4\end{array}$ & $138.60 \pm 1.77$ & $474.93 \pm 21.08$ & $\begin{array}{c}1033.06 \pm \\
41.71\end{array}$ & $\begin{array}{l}1785.10 \pm \\
57.95\end{array}$ & $\begin{array}{c}2668.66 \pm \\
65.16\end{array}$ & $\begin{array}{l}3325.15 \pm \\
58.08\end{array}$ \\
\hline $\begin{array}{c}\mathrm{T} 2 \\
\mathrm{BMD}-50\end{array}$ & $136.93 \pm 2.63$ & $498.13 \pm 5.82$ & $\begin{array}{c}1068.93 \pm \\
17.98\end{array}$ & $\begin{array}{c}1813.93 \pm \\
45.71\end{array}$ & $\begin{array}{c}2699.53 \pm \\
57.91\end{array}$ & $\begin{array}{l}3305.51 \pm \\
83.77\end{array}$ \\
\hline $\begin{array}{c}\mathrm{T} 3 \\
\mathrm{CP}-1000\end{array}$ & $137.70 \pm 5.54$ & $476.70 \pm 15.85$ & $\begin{array}{l}1011.76 \pm \\
21.66\end{array}$ & $\begin{array}{c}1750.46 \pm \\
39.83\end{array}$ & $\begin{array}{c}2692.36 \pm \\
49.69\end{array}$ & $\begin{array}{c}3350.06 \pm \\
67.99\end{array}$ \\
\hline $\begin{array}{c}\mathrm{T} 4 \\
\mathrm{CP}-2000\end{array}$ & $148.93 \pm 5.63$ & $527.70 \pm 2.62$ & $\begin{array}{c}1096.93 \pm \\
19.07\end{array}$ & $1863.26 \pm 8.65$ & $\begin{array}{c}2810.13 \pm \\
22.98\end{array}$ & $\begin{array}{c}3557.05 \pm \\
40.95\end{array}$ \\
\hline $\begin{array}{c}\mathrm{T} 5 \\
\mathrm{SB}-500\end{array}$ & $142.76 \pm 1.04$ & $489.80 \pm 9.52$ & $\begin{array}{c}1052.56 \pm \\
15.09\end{array}$ & $\begin{array}{l}1789.73 \pm \\
18.08\end{array}$ & $\begin{array}{c}2665.70 \pm \\
44.96\end{array}$ & $\begin{array}{l}3332.43 \pm \\
51.89\end{array}$ \\
\hline $\begin{array}{c}\text { T6; } \\
\text { SB }-1000\end{array}$ & $144.56 \pm 0.82$ & $515.63 \pm 5.87$ & $\begin{array}{c}1075.66 \pm \\
14.48\end{array}$ & $\begin{array}{l}1841.73 \pm \\
29.64\end{array}$ & $\begin{array}{l}2743.90 \pm \\
31.08\end{array}$ & $\begin{array}{c}3443.59 \pm \\
42.06\end{array}$ \\
\hline $\begin{array}{c}\mathrm{T} 7 \\
\mathrm{CP}-1000+\mathrm{SB}-500\end{array}$ & $142.20 \pm 4.59$ & $488.70 \pm 7.23$ & $\begin{array}{c}1063.70 \pm \\
19.73\end{array}$ & $\begin{array}{l}1818.90 \pm \\
21.82\end{array}$ & $\begin{array}{l}2741.40 \pm \\
56.51\end{array}$ & $\begin{array}{l}3351.69 \pm \\
71.20\end{array}$ \\
\hline F value & 1.633 & 2.274 & 1.248 & 0.874 & 0.974 & 1.699 \\
\hline Significance & NS & NS & NS & NS & NS & NS \\
\hline
\end{tabular}


Table.4 Effect of in fed calcium propionate (CP) and coated sodium butyrate (SB) as growth promoters on feed efficiency in commercial broiler chicken (Mean $\pm \mathrm{SE}$ )

\begin{tabular}{|c|c|c|c|c|c|c|}
\hline \multirow{2}{*}{$\begin{array}{c}\text { Treatment } \\
(\text { ppm })\end{array}$} & \multicolumn{6}{|c|}{ Experimental period (wks) } \\
\hline & 1 & 2 & 3 & 4 & 5 & 6 \\
\hline $\begin{array}{c}\mathrm{C} ; \\
\text { Control }\end{array}$ & $1.275 \pm 0.02$ & $1.393 \pm 0.04$ & $1.438 \pm 0.03$ & $1.520 \pm 0.03$ & $1.624 \pm 0.02$ & $1.751 \pm 0.34$ \\
\hline $\begin{array}{c}\mathrm{T} 1 ; \\
\text { Lincomycin } \mathrm{HCl}-4.4\end{array}$ & $1.355 \pm 0.06$ & $1.436 \pm 0.02$ & $1.474 \pm 0.01$ & $1.582 \pm 0.02$ & $1.658 \pm 0.01$ & $1.798 \pm 0.00$ \\
\hline $\begin{array}{c}\text { T2; } \\
\text { BMD }-50\end{array}$ & $1.295 \pm 0.05$ & $1.439 \pm 0.02$ & $1.480 \pm 0.02$ & $1.554 \pm 0.04$ & $1.652 \pm 0.03$ & $1.755 \pm 0.04$ \\
\hline $\begin{array}{c}\mathrm{T} 3 \\
\mathrm{CP}-1000\end{array}$ & $1.362 \pm 0.07$ & $1.461 \pm 0.03$ & $1.477 \pm 0.01$ & $1.571 \pm 0.02$ & $1.691 \pm 0.00$ & $1.795 \pm 0.01$ \\
\hline $\begin{array}{c}\mathrm{T} 4 \\
\mathrm{CP}-2000\end{array}$ & $1.361 \pm 0.04$ & $1.505 \pm 0.02$ & $1.515 \pm 0.06$ & $1.567 \pm 0.05$ & $1.656 \pm 0.05$ & $1.812 \pm 0.04$ \\
\hline $\begin{array}{c}\mathrm{T} 5 \\
\mathrm{SB}-500\end{array}$ & $1.295 \pm 0.02$ & $1.448 \pm 0.01$ & $1.474 \pm 0.01$ & $1.580 \pm 0.00$ & $1.645 \pm 0.00$ & $1.771 \pm 0.01$ \\
\hline $\begin{array}{c}\text { T6; } \\
\text { SB }-1000\end{array}$ & $1.377 \pm 0.04$ & $1.476 \pm 0.01$ & $1.486 \pm 0.02$ & $1.572 \pm 0.02$ & $1.691 \pm 0.03$ & $1.817 \pm 0.03$ \\
\hline $\begin{array}{c}\mathrm{T} 7 ; \\
\mathrm{CP}-1000+\mathrm{SB}-500\end{array}$ & $1.333 \pm 0.05$ & $1.439 \pm 0.00$ & $1.475 \pm 0.00$ & $1.542 \pm 0.02$ & $1.673 \pm 0.04$ & $1.797 \pm 0.02$ \\
\hline F value & 0.524 & 1.569 & 0.495 & 0.449 & 0.537 & 0.618 \\
\hline Significance & NS & NS & NS & NS & NS & NS \\
\hline
\end{tabular}


Table.5 Effect of in fed calcium propionate (CP) and coated sodium butyrate (SB) as growth promoters on the production cost, European Economic Factor and Average daily gain (g) in commercial broiler chicken

\begin{tabular}{|c|c|c|c|c|c|c|}
\hline \multirow{2}{*}{$\begin{array}{c}\text { Treatment } \\
(\mathbf{p p m})\end{array}$} & \multicolumn{3}{|c|}{ Feed cost (Rs./kg) } & \multirow{2}{*}{$\begin{array}{l}\text { Production cost } \\
\text { (Rs./kg live wt) }\end{array}$} & \multirow{2}{*}{$\begin{array}{c}\text { European } \\
\text { Economic } \\
\text { Factor }(\mathrm{EEF})\end{array}$} & \multirow{2}{*}{$\begin{array}{l}\text { Avg. daily } \\
\text { gain (g) }\end{array}$} \\
\hline & $\begin{array}{l}\text { Pre-Broiler } \\
\text { starter }\end{array}$ & $\begin{array}{l}\text { Broiler } \\
\text { starter }\end{array}$ & $\begin{array}{l}\text { Broiler } \\
\text { finisher }\end{array}$ & & & \\
\hline $\begin{array}{c}\mathrm{C} ; \\
\text { Control }\end{array}$ & 25.75 & 26.39 & 26.97 & 74.73 & 205 & 46.76 \\
\hline $\begin{array}{c}\mathrm{T} 1 ; \\
\text { Lincomycin } \mathrm{HCl}-4.4\end{array}$ & 25.79 & 26.43 & 27.02 & 74.24 & 217 & 46.79 \\
\hline $\begin{array}{c}\text { T2; } \\
\text { BMD - } 50\end{array}$ & 25.92 & 26.56 & 27.14 & 71.28 & 245 & 46.12 \\
\hline $\begin{array}{c}\text { T3; } \\
\mathrm{CP}-1000\end{array}$ & 26.50 & 27.14 & 27.73 & 72.35 & 254 & 45.55 \\
\hline $\begin{array}{c}\mathrm{T} 4 \\
\mathrm{CP}-2000\end{array}$ & 27.26 & 27.90 & 28.48 & 75.74 & 232 & 48.5 \\
\hline $\begin{array}{c}\text { T5; } \\
\text { SB - } 500\end{array}$ & 26.59 & 27.23 & 27.81 & 71.68 & 259 & 45.93 \\
\hline $\begin{array}{c}\text { T6; } \\
\text { SB - } 1000\end{array}$ & 27.43 & 28.07 & 28.65 & 75.39 & 240 & 46.79 \\
\hline $\begin{array}{c}\mathrm{T} 7 \\
\mathrm{CP}-1000+\mathrm{SB}-500\end{array}$ & 27.35 & 27.98 & 28.57 & 77.23 & 215 & 46.26 \\
\hline
\end{tabular}

EEF = [Livability x Average body weight / Mean Age (days) x FCR] x 100; Cost of Production=Total of all input cost/ Total Kg of Chicken sold; Production cost (per kg live weight) was calculated from the chick cost (35 Rs./chick), feed cost, miscellaneous cost (Labour cost, medicine and vaccination cost, electricity, etc.; Rs. 5 per kg live weight). 
Moreover, organic acid (acetic acid) supplementation increased the water consumption even in heat stressed birds that resulted in enhanced performance and immune response than control birds (Hassan et al., 2009). Besides, butyrate induced the cell proliferation; migration and differentiation require BDNF- tyrosine kinase $\mathrm{B}$ signaling and may contribute to long-term beneficial effects of butyrate after ischemic injury this may resulted in reduced mortality in organic acid supplemented groups (Kim et al., 2009).

Cost of production higher in organic acid combination groups. And Higher European Economic Factor noticed in butyric acid supplemented groups. By considering the both parameter T5 (Butyric acid - 500) group was superior in performance.

\section{Cost of production and European Economic Factor}

The data pertaining to cost of production/ $\mathrm{kg}$ of live weight (Table 5) indicated that higher cost of production noted in the dietary treatment groups supplemented with organic acids in combination (T7) that had Rs.77.23 which is higher than all other treatment groups including control. Treatments like T1 (linco), T2 (BMD), T3 (CP 1000) and T5 (SB 500) bringing down the COP by Rs. 0.49, 3.45, 2.38 and 3.05, respectively when compared to control group; whereas T4 (CP 2000), T6 (SB 1000) and T7 (CP $1000+$ SB 500) had increased the COP by Rs. 1.01, Rs. 0.66 and Rs. 2.55, respectively. It was observed that the groups supplemented at lower doses of organic acid (T3 and T5) showed an increased EEF than their respective higher doses (T4 and T6) supplemented group. The group T5 (SB 500) had 54 points higher EEF than Control; 42 points higher than T1 (lincomycin); 14 points higher than T2 (BMD); 5 points higher than T3 (CP 1000); 27 points higher than T4 (CP 2000); 19 points higher than T6 (SB 1000); 44 points higher than T7 (CP $1000+$ SB 500). From these findings, it was inferred that the groups supplemented with sodium butyrate (T5) found to be superlative than other groups since mortality is zero per cent, higher EEF and reduced feed consumption than other organic acid supplemented groups.

Based on the overall performance of broilers, salts of organic acids (OAs) such as calcium propionate and coated sodium butyrate could be safely supplemented as an alternative to antibiotic growth promoters (AGPs) in the commercial broiler diet without affecting the production performance such as body weight gain, feed consumption, feed efficiency and livability. Among these two organic acid salts studied in this experiment, at various concentrations either alone or in combination, supplementation of coated sodium butyrate at $500 \mathrm{ppm}$ could be considered for achieving the overall performance with better cost of production. Salts of organic acids (OAs) could be safely supplemented as an alternative to antibiotic growth promoters (AGPs) in the commercial broiler diet to lower the risk of residues in the meat and to avoid the antibiotic resistance (if any) to the consumers.

\section{Acknowledgements}

The authors acknowledge the Tamil Nadu Veterinary and Animal Sciences University, Chennai-51 for providing all facilities to do the work.

\section{References}

Adil, S., Banday T, Bhat GA, Mir MS, and Rehman M, 2011. Response of broiler chicken to dietary supplementation of organic acids. Journal of central European Agriculture. 12(3): 498-508.

Brozoska Franciszek, Bogdan Sliwinski and Olga Michalik-Rutkowska. 2013. Effect of dietary acidifier on growth, mortality, post slaughter parameters and meat consumption of broiler chickens. Ann. Anim. Sci. 13(1): 85-96.

Cogliani, C., Goossens H and Greko C. 2011. Restricting antimicrobial use in food animals: Lessons from Europe. Micrbobe. 6(6): 274-279. 
Czerwinski, J., O. Hojberg, S. Smulikowska, R.M. Engberg and A. Mieczkowska, 2012. Effects of Sodium butyrate and salinomycin upon intestinal microbiota, mucosal morphology and performance of broiler chickens. Arch. Anim. Nutr.66 (2): 102 116.

Deepa, K., and Purushothaman MR. 2016. Sodium butyrate as an antibiotic substitute for commercial broiler chicken. M.V.Sc thesis submitted to Tamil Nadu Veterinary and Animal Sciences University, Chennai51.

Fukumoto, S., Tatewaki M, Yamada T, Fujimiya M, Mantyh CM S, Eubanks M. Harris, Takahashi T. 2003. Short-chain fatty acids stimulate colonic transit via intraluminal 5HT release in rats. Am. J. Physiol. Regul. Integr. Comp.Physiol. 284: 1269-1276

Haque, M.N., Chowdry R, Islam KMS and Akbar MA. 2009. Propionic acid as an alternative to antibiotics in poultry diet. Bangladesh Journal of Animal Science. 38(1\&2): 115122.

Hassan, A.M., Abdel Azeem HM and Reddy PG. 2009. Effect of some water supplements on the performance and immune system of chronically heat-stressed broiler chicks. International Journal of Poultry Science. 8(5): 432-436.

Hu, Z., and Guo Y. 2007. Effects of dietary Sodium butyrate supplementation on the intestinal morphologic structure, absorptive function and gut flora in chickens. Anim. Feed Sci. Technol. 132(3-4): 240-249.

Khadem, A., Soler L, Everaert $\mathrm{N}$ and Niewold TA. 2014. Growth promotion in broilers by both oxytetracycline and Macleaya cordata extract is based on their anti-inflammatory properties. British Journal of Nutrition. 112(7): 1110-1118.

Khosravi, A., Boldaji F, Dastar B and Hasani S. 2008. The use of some feed additives as growth promoter in broilers nutrition. Int. J.
Poult. Sci. 7: 1095-1099.

Kim, H.J., Leeds P and Chuang DM. 2009. The HDAC inhibitor, sodium butyrate, stimulates neurogenesis in the ischemic brain. J Neurochem. 110: 1226-1240

Lakshmi, K.V., and Sunder GS. 2015. Supplementation of Propionic Acid(PA), Butyric Acid(BA) or Antibiotic(AB) in diets and their influence on broiler performance, carcass parameters and immune response. International Journal of Science Research. 4(3): 1002-1006.

Malbert, C.H., Montfort I, Mathis C, Guerin S, Laplace JP. 1994. Remote effects of ileocolic SCFA levels on gastric motility and emptying. In: proceedings of $6^{\text {th }}$ International Symposium on Digestion Physiology in pigs. Bad Doberan (Germany). 283-286.

Midtvedt, T., 1986. Effects of antimicrobial agents upon the functional part of the intestinal flora. Scand. J. Infect. Dis. Suppl. 49: 85-88.

Mitsui, R., Ono S, Karaki S, Kuwahara A. 2005. Neural and non-neural mediation of propionate-induced contractile responses in the rat distal colon. Neuro. Gastroenterol. Motil; 17: 585-594.

Oruwari, B.W., 1993. Propionic acid and calcium propionate in diets for egg-type layer and broiler chicks. J. Applied Animal Res. 3: 73-81.

Shahir, M.H., Moradi S, Afsarian O, Esmaelipour O. 2013. Effects of cereal type, enzyme and sodium butyrate addition and growth performance, carcass traits and intestinal morphology of broilers. Braz. J. Poultry Sci. 15(3): 169-286.

Tazoe, H., Otomo Y, Kaji I, Tanaka R, Karaki SI, Kuwahara A. 2008. Roles of short-chain fatty acids receptors, GPR41 and GPR43 on colonic functions. J. Physiol. Pharmacol. 59 (2): 251-262.

\section{How to cite this article:}

Naveenkumar, S., N. Karthikeyan, R. Narendra Babu, P. Veeramani and Sivaramakrishnan, S. 2017. Effect of Organic Acid Salts as an Alternative to Antibiotic Growth Promoters on the Production Performance of Commercial Broiler Chicken. Int.J.Curr.Microbiol.App.Sci. 6(9): 3470-3480. doi: https://doi.org/10.20546/ijcmas.2017.609.426 